\title{
TRANSLATION SYMMETRY OF EDGE STATE
}

\author{
A. Matulis ${ }^{a, b}$ \\ a Semiconductor Physics Institute, Center for Physical Sciences and Technology, A. Goštauto 11, LT-01108 Vilnius, Lithuania \\ ${ }^{\mathrm{b}}$ Institute of Theoretical Physics and Astronomy, Vilnius University, A. Goštauto 12, LT-01108 Vilnius, Lithuania \\ E-mail: amatulis@takas.lt
}

Received 12 June 2013; accepted 5 July 2013

\begin{abstract}
The interplay of broken translation symmetry due to the edge and the particular properties of the edge states is illustrated considering the simple square lattice. In the case of the most symmetric edge (when its direction coincides with the primitive translation vector) the translation along the edge symmetry enables to transform the two-dimensional (2D) tight-binding method equations into a more simple 1D eigenvalue problem. When the direction of the edge does not coincide with the primitive vector, the above-mentioned symmetry is broken. Nevertheless it can be partially restored enlarging the primitive cell and the number of wave function components, what enables to obtain the above-mentioned effective 1D problem. It is shown that the exact solution of the 1D problem can be obtained by means of the Bethe Ansatz method what was checked by the numerical diagonalization. Using the proposed technique the properties of the edge states were considered. It was shown that there are two reasons for the edge states to appear: the local potential of the edge sites and the modification of the tunnelling amplitudes along the edge. In the case of the most symmetric edge only the second one can lead to the edge state energy dependence differing from the one of the bottom of the continuous band. While in the case of the tilted edge the electron motion along the edge infuences significantly the spectrum of the edge state.
\end{abstract}

Keywords: square lattice, tilted edge, Bethe Ansatz

PACS: 73.20.-r, 73.22.-f, 73.90.+f

\section{Introduction}

Since its isolation in 2004, graphene [1] - the twodimensional (2D) system of electrons - is still of interest because of nontrivial electronic properties and promising applications in electronic devices. Due to the progress in nanotechnology the investigations are shifting towards the properties of restricted systems, like half-planes and ribbons where the edges are of importance (see [2] and references there). The restrictions always lead to more complicated calculations. That is why the application of various symmetries that simplifies the consideration is of importance. For instance, looking for the protected edge states much attention to the topological symmetry is given [3], expecting that such states inffuence essentially the transport and magnetic properties of the restricted samples.
To our mind, the translation symmetry might be useful as well when considering the properties of the edge states. Although the edge always spoils the translation symmetry (at least partially), the remaining of it enables to reduce the dimensionality of the problem, and in such way simplifies the consideration. In the case of edge states in graphene the reference of attention to the translation symmetry is important as well. Usually two types of edges are under consideration: zigzag and armchair [4]. The first one is cut along the direction of the primitive translation vector, while the second one makes a $30^{\circ}$ angle with it. This fact provides different properties of these edges because they spoil the translation symmetry of the graphene lattice in a different way.

The above-mentioned influence of the translation symmetry on the edge state properties is 
caused by the disreteness of the lattice, and it is not just the prerogative of the graphene. It can be met in a more simple lattice as well. The aim of this paper is to demonstrate the interplay of the spoiled translation symmetry and the edge state properties using the simplest model quadratic lattice. This model was successfully used to consider the main properties of the topologial isolators [5]. Besides, we pursue the methodologial purpose and show how making use of the translation symmetry the $2 \mathrm{D}$ lattice eigenvalue problem can be transformed into a $1 \mathrm{D}$ effective chain problem in the case of any edge. The latter one is considered by means of Bethe Ansatz [ [6].

The paper is organized as follows. In Section 2 we present the model and shortly formulate the tight-binding model equations. The main idea of using the translation symmetry in edge state treatment is given in Section 3 considering the most symmetric edge, while in Section 4 the appliation of Bethe Ansatz in solving the effective 1D chain model is presented. In Sections 5 and 6 the same procedure is applied to the tilted edge, and in Section 7 our conclusions are given.

\section{Model}

We consider the model system shown in Fig. 1 and describe the spectrum of electron moving in this square $2 \mathrm{D}$ lattice by the following stationary tightbinding model (TBM) equation:

$$
\varepsilon u_{n, m}=-\left(u_{n-1, m}+u_{n+1, m}+u_{n, m-1}+u_{n, m+1}\right) .
$$

The symbol $\varepsilon$ stands for the electron energy (measured in tunnelling amplitude units), and $u_{n, m}$ is the amplitude whose modulus squared indicates the probability to find the electron at the lattice site $\{n, m\}$. According to the figure the vertial rows of the lattice are numbered by the first index $n$, while the second index $m$ shows the number of the horizontal ones.

The lattice can be considered as constructed translating the shadowed primitive cell along the directions of the primitive translation vectors $\mathbf{a}$ and b shown by arrows. It is evident that this infinite lattice and Eq. (1) are also invariant in respect of these two translations. Consequently, the amplitude can be presented as a product of the eigenfunctions of the corresponding translation operators

$$
u_{n, m}=\mathrm{e}^{\mathrm{i}(k n+q m)}
$$

with the real quasi-momentum components $k$ and $q$ what leads to a well-known cosine type spectrum:

$$
E=\varepsilon+4=4-2(\cos k+\cos q) .
$$

For the sake of convenience we introduced the shifted-up energy in order to have the bottom of the band at the point $E=0$.

\section{The most symmetric edge}

We start the analysis of the edge states with the half-lattice shown in Fig. 2 with the vertical edge on its left side. It is of the most symmetry and corresponds to the zigzag edge in a graphene ribbon.

The amplitudes of the electron moving in this lattice satisfy the same Eq. (1) with a single differene that now $n \geq 1$. The amplitudes at the edge

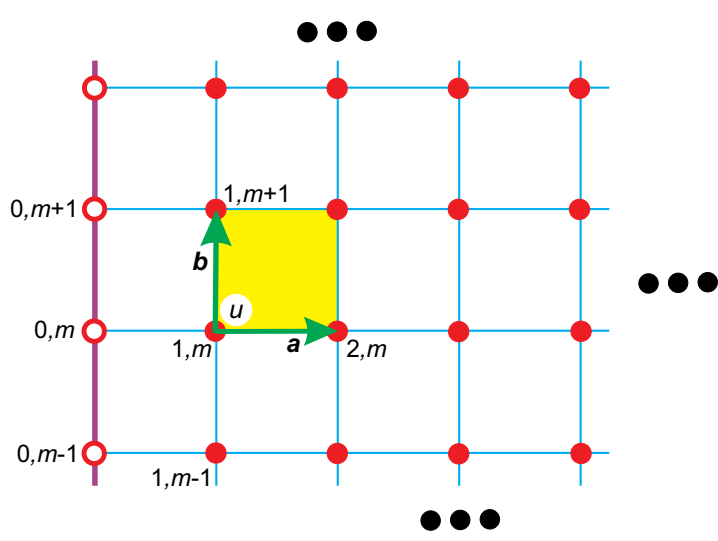

Fig. 2. Half-lattice with the most symmetric edge along $\mathbf{b}$ direction.

Fig. 1. Square 2D lattice. 
(its sites are shown by the empty circles) satisfy the following boundary condition:

$$
(\varepsilon-U) u_{0, m}=-u_{1, m}-s\left(u_{0, m-1}+u_{0, m+1}\right) .
$$

This equation differs from the previous Eq. (1) not only by the number of nearest neighbours (three instead of four), but also by the additional local energy $U$ and modified tunnelling amplitude along the edge by factor $s$, what can be justified by the different hybridization of the edge atom states and their different interaction with the substrate.

The symmetry properties of this half-lattice are weaker compared with those of the infinite lattice. For instance, it is not invariant in respect of translation perpendicular to the edge direction along vector a. That is why the amplitude given by Eq. (2) is not a solution anymore. However, this half-lattice is still invariant in respect of its translation along vector $\mathbf{b}$. Consequently, the eigenfunction of this translation operator can be used, and the problem can be reduced to the effective $1 \mathrm{D}$ eigenvalue problem. Namely, we assume the following amplitude:

$$
u_{n, m}=\mathrm{e}^{\mathrm{i} q m} u_{n}
$$

and inserting it into Eqs. (1) and (4) obtain the following set of equations:

$$
\begin{aligned}
& (\varepsilon+2 \cos q) u_{n}=-\left(u_{n-1}+u_{n+1}\right), \\
& {\left[\varepsilon+2 \cos q-U_{\text {eff }}(\mathrm{q})\right] u_{0}=-u_{1},}
\end{aligned}
$$

where

$$
U_{\text {eff }}(q)=U+2(1-s) \cos q .
$$

Actually, we separated the variables, and the main characteristic of the parallel motion, the electron momentum $q$ along the edge, enters the above set of equations as a plain parameter. It causes the total shift of the energy spectrum and modifies the local potential of the edge sites. In such way we managed to simplify the $2 \mathrm{D}$ problem essentially, reducing it to the $1 \mathrm{D}$ one. Actually, we converted it to the eigenvalue problem of the chain that is shown in Fig. 3 .

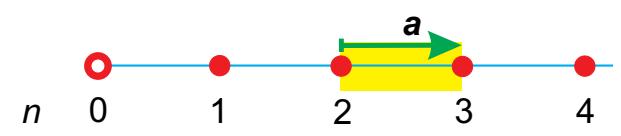

Fig. 3. The effective chain.

\section{Bethe Ansatz}

So, in order to find the edge state of a 2D lattice we have to find the edge state of a 1D chain shown in Fig. 3. From the first sight it seems that the translation symmetry cannot help us anymore, because due to the edge this half-chain is not invariant in respect of this symmetry. However, there is the socalled Bethe Ansatz [6] that is closely related to the above symmetry and often enables to find the exact analytical solution. The main idea of this method consists in constructing the solution of a half-infinite chain as a superposition of exponents (the eigenfunctions of the translation operator). Such superposition satisfies Eq. (6a) automatically, and the single job to do is to satisfy the boundary condition (6b) choosing properly the coefficients of it. We shall illustrate this idea solving our simple most symmetric edge problem.

Thus, inserting exponent

$$
u_{n}=\mathrm{e}^{\mathrm{i} k n}
$$

into Eq. (6a) we obtain Eq. (3) for the continuous spectrum. As this equation is an even function of momentum $k$ the superposition of two exponents with $\pm k$ may be constructed, what leads to the known solution of the reflected wave from the edge of the chain. We are looking, however, for a different solution, namely, for the edge state with the energy that is lower than the bottom of the above continuous spectrum. Fortunately, such solution can be obtained from the above one just replacing $k \rightarrow \mathrm{i} \kappa$, what gives the amplitude

$$
u_{n}=e^{-\kappa n},
$$

decaying when receding from the edge $(n \rightarrow \infty)$, and the energy

$$
\varepsilon=-2(\cos q+\operatorname{ch} k)
$$

that is lower than the bottom of the continuous spectrum. In this case, however, there is no other solution because changing $\kappa \rightarrow-\kappa$ we obtain the solution growing when receding from the edge. Consequently, the boundary condition ( $6 \mathrm{~b}$ ) has to be satisfied by a single exponent (9). Thus, inserting this exponent into Eq. (6b) and using Eq. (6a) we obtain

$$
U_{\text {eff }}(q)=-\mathrm{e}^{\kappa} .
$$


We see that a single discrete edge state appears if this effective edge potential is negative and its absolute value exeeds the unity $\left(U_{\text {eff }}<-1\right)$. Solving the above equation for $\kappa$ and inserting it into Eq. (10) we obtain the energy of the local edge state, corresponding to the above $\kappa$ :

$$
\begin{aligned}
& E=4-2 \cos q+U_{\text {eff }}(q)+\frac{1}{U_{\text {eff }}(q)} \\
& =E_{\text {min }}(q)+\left(2+U_{\text {eff }}+\frac{1}{U_{\text {eff }}}\right)
\end{aligned}
$$

where

$$
E_{\text {min }}(q)=E(0, q)=2(1-\cos q)
$$

is the above-mentioned bottom of the continuous spectrum for the given parallel momentum $q$ value. The obtained result is illustrated by Fig. 4 where the spectrum is shown. We see that when the tunnelling along the edge is the same as in the plane $(s=1)$, the edge state is pushed down from the bottom of the continuous spectrum parallel to its minimum (see solid line in Fig. 4). In the opposite $(s \neq 1)$ case the effective edge potential (7) is $q$-dependent, and when the momentum $q$ increases the edge state either submerges itself into continuum or splits away from it at some $q$ value, as it is shown by dashed and dotted curves.

The analogous localized state can be pushed up from the top of the continuous spectrum when $U_{\text {eff }}(q)>1$. In this case the function $u_{n}=(-1)^{n} \exp (-\kappa n)$ has to be chosen. It is remarkable that the local state appears when the positive effective potential exceeds only one fourth of the

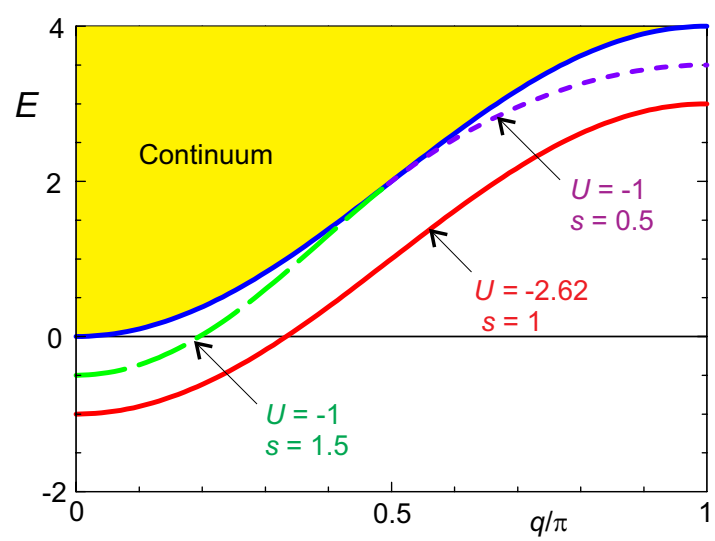

Fig. 4. Edge state in the most symmetric edge case. continuous spectrum width like in the alreadyconsidered negative local potential case.

\section{Tilted edge}

Now we consider a more sophisticated case when the edge is tilted and spoils the translation symmetry substantively. The example of such edge is shown in Fig. 5. It is evident that this half-lattice is not invariant in respect of both translations along the previously defined primitive vectors $\mathbf{a}$ and $\mathbf{b}$.

However, the translation symmetry can be partially restored choosing some other primitive cell as it is shown in Fig. 6. Now the edge spoils the translation symmetry only in the direction of vector $\mathbf{a}$ while the other one along vector $\mathbf{b}$ is preserved as its direction coincides with the direction of the edge that is shown by the tilted dashed line. In the case of some other tilted edges the different cells (maybe even larger) have to be chosen. This choice is closely related to the commensurability

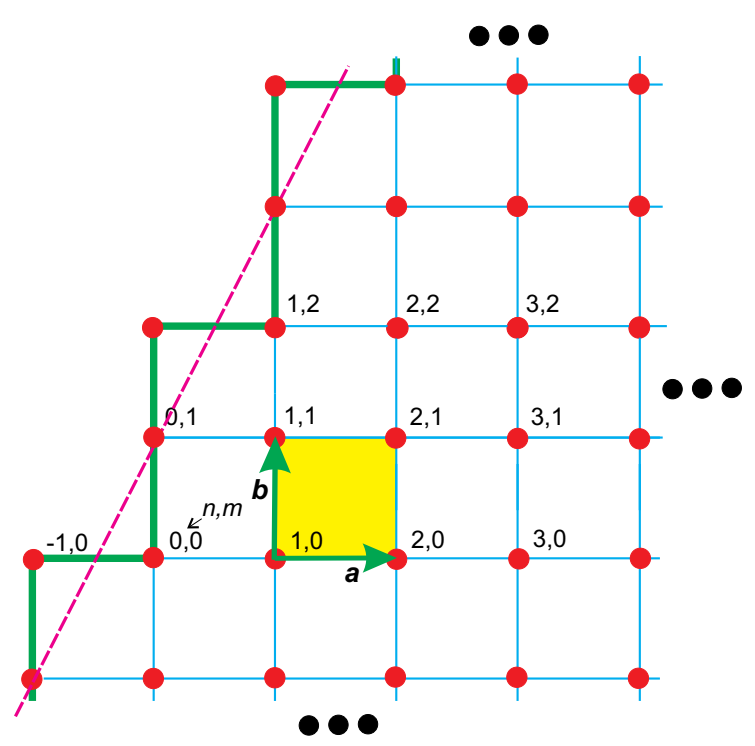

Fig. 5. Half-lattice with the tilted edge.

in the system with twofold periodicity (lattice and edge), like in the case of the lattice with the magnetic field [f].

We see in Fig. 6 that now there are two atoms in the primitive cell (they are indicated by circles and squares). Consequently, two-component electron amplitudes have to be used, and instead of Eqs. (1) and (4) they satisfy the following set of four equations: 


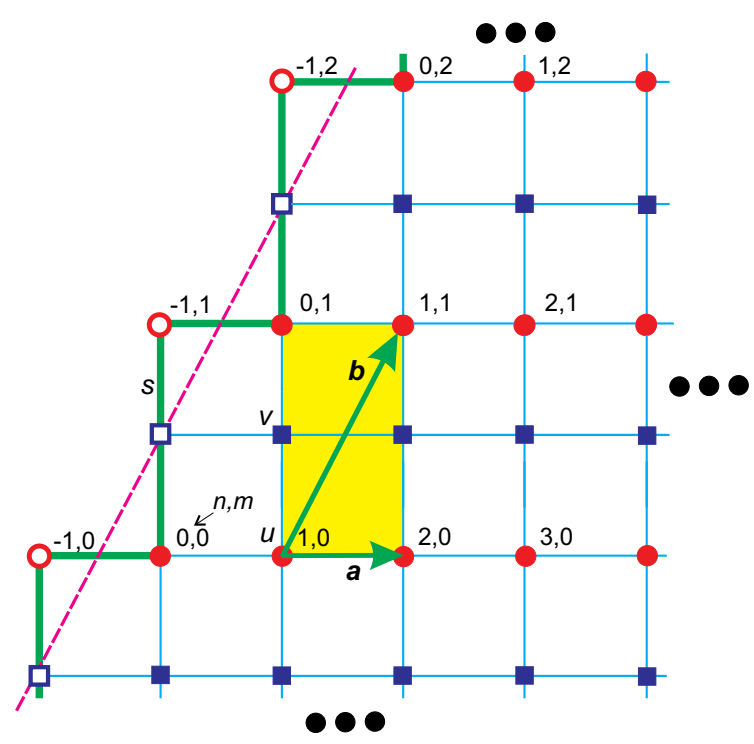

$$
\begin{aligned}
& (\varepsilon-U) u_{0}=-\left(u_{1}+\mathrm{e}^{-\mathrm{i} q} v_{0}+s v_{-1}\right), \\
& (\varepsilon-V) v_{-1}=-\left(v_{0}+s u_{0}\right),
\end{aligned}
$$

that describes the motion of the electron in the effective $1 \mathrm{D}$ chain shown in Fig. ㄱ.

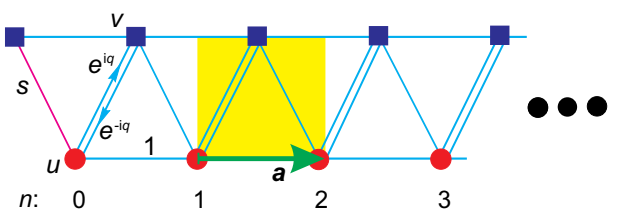

Fig. 7. Effective 1D chain for the tilted edge problem.

Fig. 6. Twice large primitive cell.

$$
\begin{aligned}
& \varepsilon u_{n, m}=-\left(u_{n-1, m}+u_{n+1, m}\right. \\
& \left.+v_{n, m-1}+v_{n-1, m}\right), \quad n \geq 1 ; \\
& \varepsilon v_{n, m}=-\left(v_{n-1, m}+v_{n+1, m}\right. \\
& \left.+u_{n+1, m}+u_{n, m+1}\right), \quad n \geq 0 ; \\
& (\varepsilon-U) u_{0, m}=-\left(u_{1, m}+v_{0, m-1}+s v_{-1, m}\right), \\
& (\varepsilon-V) v_{-1, m}=-\left(v_{0, m}+s u_{0, m}\right) .
\end{aligned}
$$

Now following the strategy presented in Sec. 3 and using the restored symmetry along the edge we assume the following amplitudes:

$$
\left(\begin{array}{l}
u_{n, m} \\
v_{n, m}
\end{array}\right)=e^{\mathrm{i} q m}\left(\begin{array}{l}
u_{n} \\
v_{n}
\end{array}\right),
$$

where the symbol $q$ stands for the electron momentum component along the tilted edge. Inserting these amplitudes into Eqs. (14) we obtain the following set of $1 \mathrm{D}$ difference equations:

$$
\begin{aligned}
& \mathcal{\varepsilon} u_{n}=-\left(u_{n-1}+u_{n+1}\right. \\
& \left.+\mathrm{e}^{-\mathrm{i} q} v_{n}+v_{n-1}\right), \quad n \geq 1 ; \\
& \varepsilon v_{n}=-\left(v_{n-1}+v_{n+1}\right. \\
& \left.+u_{n+1}+\mathrm{e}^{\mathrm{i} q} u_{n}\right), \quad n \geq 0 ;
\end{aligned}
$$

and inserting it into the Eqs. (16a) and (16b) obtain the following set of two algebraic equations:

$$
\begin{aligned}
& {[\varepsilon+2 \cos k] u=-\left(\mathrm{e}^{-\mathrm{i} q}+\mathrm{e}^{-\mathrm{i} k}\right) v,} \\
& {[\varepsilon+2 \cos k] v=-\left(\mathrm{e}^{\mathrm{i} k}+\mathrm{e}^{\mathrm{i} q}\right) u .}
\end{aligned}
$$

By zeroing the determinant of the above set we obtain the dispersion relation

$$
\varepsilon_{ \pm}=-2 \cos k \pm 2 \cos [(k-q) / 2] \text {. }
$$

Actually, it coindices with the obtained earlier Eq. (3) if we take into account the skewness of coordinates in the momentum plane defined by new primitive vectors $\mathbf{a}$ and $\mathbf{b}$ and a twice smaller Brillouin zone due to which two energy branches appear. This dispersion relation differs, however, essentially from Eq. (3) that was used in the case of the most symmetric edge. Due to the second term the variables are not separated, and it is not possible to satisfy the above equation with imaginary momentum $k$ that we need for describing the 
edge state. That is why let us try a complex momentum

$$
k=\xi+\mathrm{i} \kappa, \quad \kappa>0,
$$

and split Eq. (19) into real and imaginary parts:

$$
\begin{aligned}
& \varepsilon_{ \pm}=-2 \cos \xi \operatorname{ch} \kappa \pm 2 \cos [(\xi-q) / 2] \operatorname{ch}(\kappa / 2), \\
& -2 \sin \xi \operatorname{ch}(\kappa / 2) \pm \sin [(\xi-q) / 2]=0
\end{aligned}
$$

The graphical solution of these equations for the momentum $k$ components (20) in the case of a given energy $E$ is demonstrated in Fig. 8 where the zero lines of two contour plots corresponding to above two equations are shown.

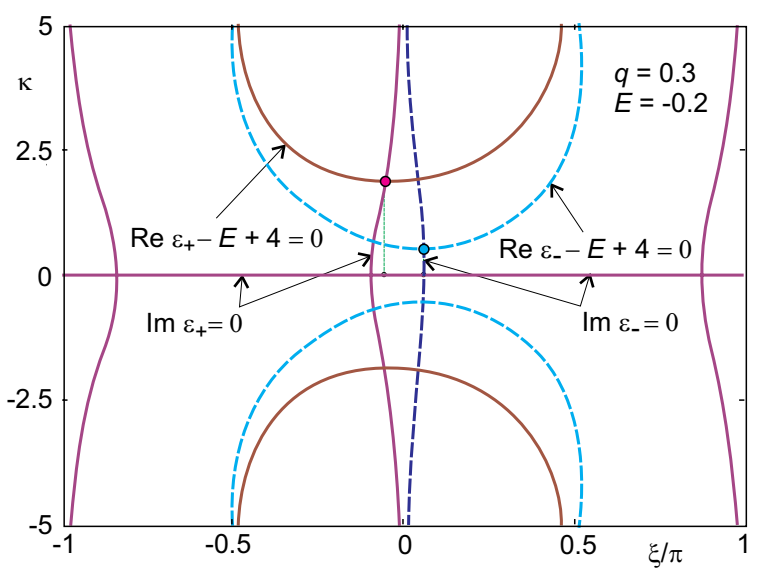

Fig. 8. Graphical solution of Eqs. (21).

The solutions are obtained as intersections of solid or dashed curves corresponding to the real and imaginary parts of dispersion equations. Two of them in the upper half-plane that according to Eq. (20) are useful for constructing the edge state are indicated by circles. This contour plot confirms our assumption that dispersion equations can be satisfied by the complex momentum $k$ value.

By the way, the solution can be simplified using the analytic expression for the imaginary part of the momentum obtained from Eq. (21b):

$$
\begin{aligned}
& \operatorname{ch}\left(\kappa_{ \pm} / 2\right)= \pm \frac{\sin \left[\left(\xi_{ \pm}-q\right) / 2\right]}{2 \sin \xi_{ \pm}} \\
& \operatorname{ch} \kappa_{ \pm}=2 \operatorname{ch}^{2}\left(\kappa_{ \pm} / 2\right)-1 .
\end{aligned}
$$

Now, inserting these expressions into Eq. (21a) we obtain the energy as an even function of the real momentum component:

$$
E=4+2 \cos \xi+\frac{\cos q-\cos \xi}{2 \sin ^{2} \xi} .
$$

Thus, the root of this real equation (what can be easily obtained numerically, say, by the NewtonRaphson method) together with Eq. (22) gives us both momentum $k_{+}$components. The energy dependence of them is illustrated by Fig. 9 .

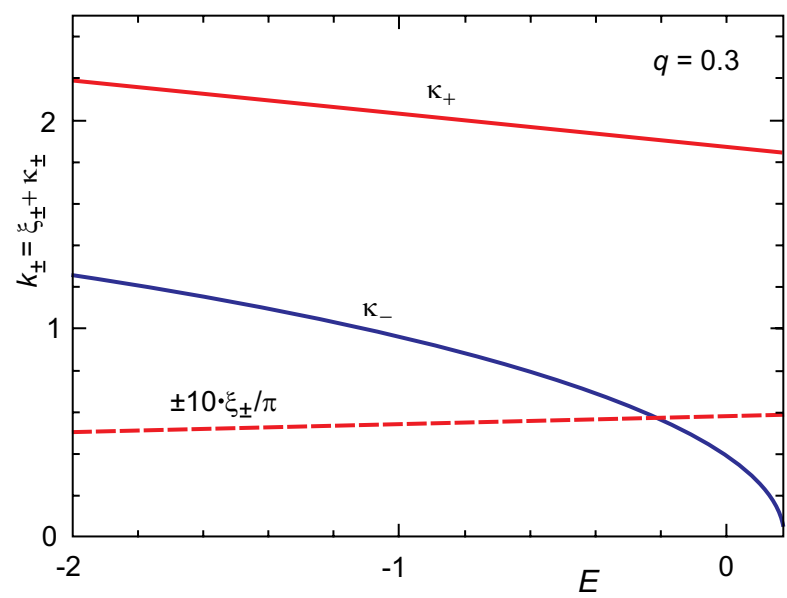

Fig. 9. Energy dependence of real and imaginary momentum components for the edge state.

We see that approaching the bottom of the continuous band ( $E=0.22$ in the case of $q=0.3$ ) the imaginary component $k_{-}$becomes zero, what indicates that at this point the edge state (if it existed) breaks away from the edge and submerges into a continuous band.

When the momenta are found, the components of amplitudes (17) are obtained by means of Eq. (18a):

$$
\left(\begin{array}{l}
u \\
v
\end{array}\right)_{ \pm}=\left(\begin{array}{l}
u_{ \pm} \\
v_{ \pm}
\end{array}\right)=\left(\begin{array}{l}
\mathrm{e}^{-\mathrm{i} k_{ \pm} / 2} \\
\mp \mathrm{e}^{\mathrm{i} q / 2}
\end{array}\right)=\left(\begin{array}{l}
\mathrm{e}^{ \pm \mathrm{i} \xi / 2+\kappa_{ \pm} / 2} \\
\mp \mathrm{e}^{\mathrm{i} q / 2}
\end{array}\right) .
$$

Now we use the ideas of Bethe Ansatz and construct the following wave function of the electron:

$$
\Psi_{n}=A \mathrm{e}^{\mathrm{i} k n n}\left(\begin{array}{l}
\mathrm{e}^{-\mathrm{i} k / 2} \\
\mathrm{e}^{\mathrm{i} q / 2}
\end{array}\right)+B \mathrm{e}^{i k+n}\left(\begin{array}{l}
\mathrm{e}^{-\mathrm{i} k_{+} / 2} \\
-\mathrm{e}^{\mathrm{i} q / 2}
\end{array}\right) .
$$


Inserting this function into boundary conditions (16c) and (16d) we obtain the set of two algebraic equations:

$$
\begin{aligned}
& a \mathrm{e}^{-\mathrm{i} k_{-}} A+b \mathrm{e}^{-\mathrm{i} k_{+}} B=0, \\
& c \mathrm{e}^{-\mathrm{i}\left(k_{-}-q\right) / 2} A-d \mathrm{e}^{-\mathrm{i}\left(k_{+}-q\right) / 2} \mathrm{~B}=0,
\end{aligned}
$$

where

$$
\begin{aligned}
& a=U \mathrm{e}^{\mathrm{i} k_{-} / 2}+\mathrm{e}^{-\mathrm{i} k_{-} / 2}+(1-s) \mathrm{e}^{\mathrm{i} q / 2}, \\
& b=U \mathrm{e}^{\mathrm{i} k_{+} / 2}+\mathrm{e}^{-\mathrm{i} k_{+} / 2}-(1-s) \mathrm{e}^{\mathrm{i} q / 2}, \\
& c=(\varepsilon-V) \mathrm{e}^{-\mathrm{i} k_{-} / 2}+\mathrm{e}^{\mathrm{i} k_{-} / 2}+s \mathrm{e}^{-\mathrm{i} q / 2}, \\
& d=(\varepsilon-V) \mathrm{e}^{-\mathrm{i} k_{+} / 2}+\mathrm{e}^{\mathrm{i} k_{+} / 2}-s \mathrm{e}^{-\mathrm{i} / 2} .
\end{aligned}
$$

At last, zeroing the determinant we get

$$
D(E)=\mathrm{e}^{-\mathrm{i} k_{-} / 2} a d+\mathrm{e}^{-\mathrm{i} k+/ 2} b c=0 .
$$

Actually, it is the equation from which the energy of the edge state (if such state exits) has to be defined. The energy, of course, is a real quantity (otherwise the state will not be stationary), while Eq. (28) itself is complex. It is equivalent to two real equations for real and imaginary parts of Eq. (28). That is why it is not evident that the edge state exists. And if it exists it is not evident that the applied Bethe Ansatz method gives the right answer. There are known cases when this method fails (see, for instance [8]). The positive answer to this question we see in Fig. 10 where the energy dependence of real and imaginary parts of the above determinant is shown. We see that these components become zero at the same energy value indicated by an empty circle. The coincidence within the accuracy of six digits cannot be occasional.

The validity of obtained results by means of Bethe Ansatz was confirmed by the direct numerical diagonalization of the matrix corresponding to considered Eqs. (16). The typical result for the ribbon of the width of 30 primitive cells $(0 \leq n<30)$ is shown in Fig. 11. The obtained 60 energy values are shown in the increasing order for two different $q$ values. The most interesting for us are the kinks of both curves at small $n$ values indicated by the empty circle, witnessing the existence of the edge states split from the continuous spectrum. These numerical values coin-

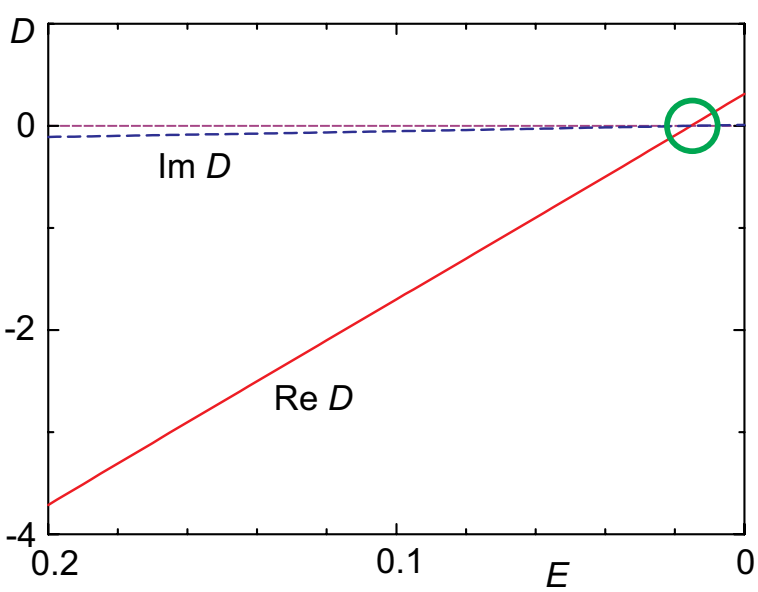

Fig. 10. Energy dependence of real and imaginary components of the determinant (28).

cide with those obtained for the edge state energy by means of Bethe Ansatz within $0.1 \%$ accuracy.

Figure 12 demonstrates the behaviour of the edge state wave function components that are real in this $q=0$ case. According to the Bethe Ansatz method the wave function consists of two exponents (slow and fast) that are shown separately. Both components in a slow exponent are of the same sign and almost coincide. A small difference appears due to the different position of sites in the primitive cell, and it shortly disappears when going away from the edge where the discreteness of the lattice becomes not important. In the fast exponent, the components are of the opposite sign. They are essential only in the near vicinity of the edge and take

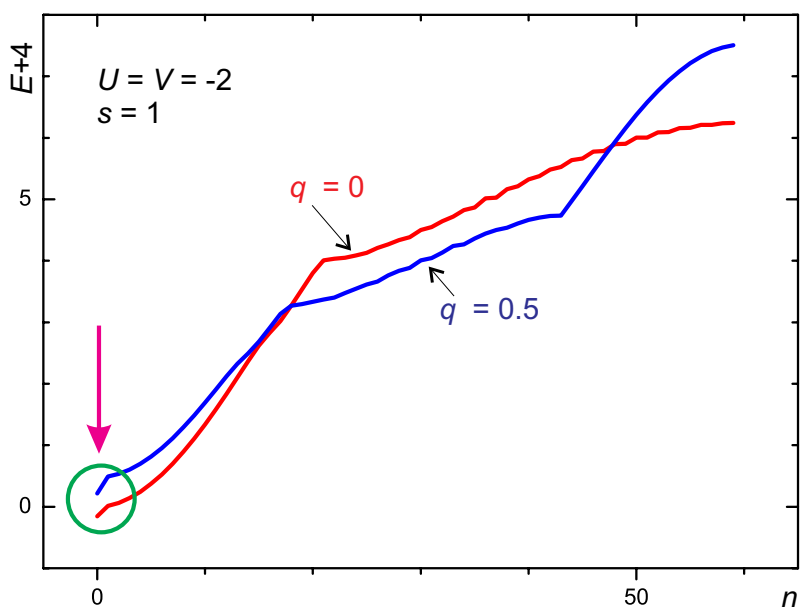

Fig. 11. The eigenvalues obtained by numerical diagonalization. 


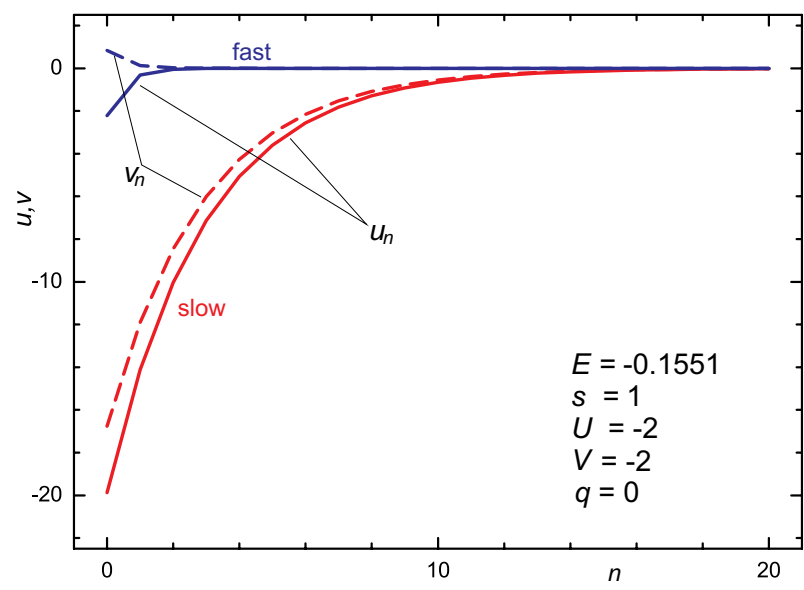

Fig. 12. The wave function of the edge state. Two exponent components $u_{n}$ are shown by solid curves, while $v_{n}$ by dashed ones.

into account the wave function corrections due to the discreteness and scalariform of the edge.

The energy of the edge state as a function of the momentum component $q$ along the edge is shown in Fig. 13 together with the shadowed continuous spectrum. Comparing this plot with the results for the most symmetric edge presented in Fig. 4 we may conclude that in the case of the tilted edge the motion of the electron along the edge is more tightly coupled with its motion in the perpendicular direction that finally is responsible for the appearance of the edge state. Two factors testify to it: the edge state energy split dependence on the parallel electron momentum (even in the case of non-modified tunneling when $s=1$ ), and increasing the above-mentioned split with increment of this momentum.

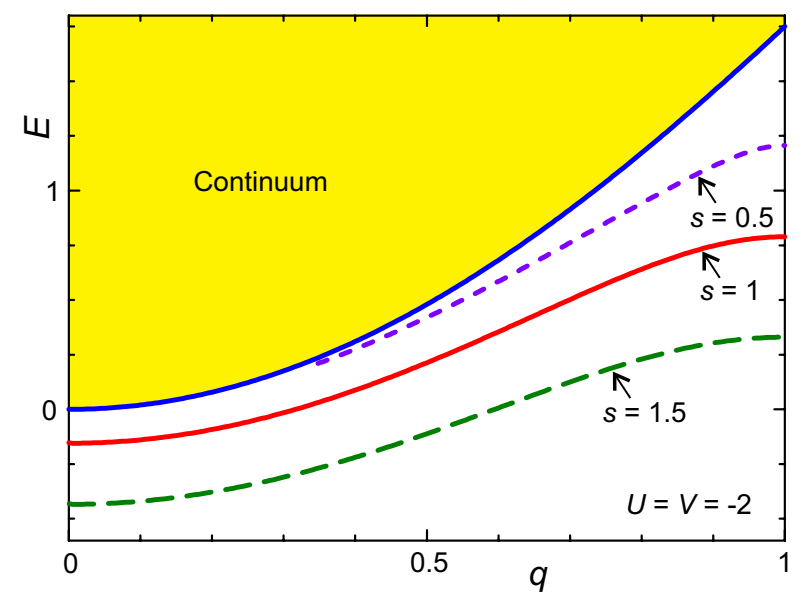

Fig. 13. Spectrum in the case of tilted edge for different tunnelling amplitudes along the edge.

\section{Conclusions}

Using the simplest model of the 2D quadratic lattice, the interplay between the lattice edge and translation symmetry was demonstrated. It was shown that due to translation symmetry the $2 \mathrm{D}$ lattice eigenvalue problem can be transformed into the $1 \mathrm{D}$ chain problem. When the edge is cut along a primitive translation vector, it does not spoil the translation symmetry along the edge. The variables can be separated, and the above transformation is trivial.

In the case of the tilted edge when its direction does not coincide with any primitive translation vector, sometimes it is possible to restore the spoiled symmetry by means of increasing the primitive cell and changing the corresponding translation vectors. That enables to reduce the $2 \mathrm{D}$ problem to the $1 \mathrm{D}$ one, although by enlarging the number of wave function components. Thus, we may conclude that the tilted edge breaks the translation symmetry only partially.

We showed that although there is no translation symmetry perpendicularly to the edge direction, the obtained $1 \mathrm{D}$ eigenvalue problem can be exactly solved using the Bethe Ansatz method, namely, using the wave function as a superposition of the translation operator eigenfunctions, what may be explained by the one-dimensionality of the problem and the local type of perturbation caused by the edge.

Using the proposed technique, the properties of the edge states were considered. There are two reasons for the edge state to appear. The first one is just the local potential of edge sites. If this potential is negative and exceeds some critical value, the edge state is pushed down from the bottom of the continuous spectrum. In an analogous way, the positive local potential can push the edge state up from the top of the continuous spectrum. The second reason for the edge state to appear is a dynamical one. The different tunnelling of the electron along the edge changes the local potential into the effective one that modifies the condition for the edge state to appear and makes the edge state energy dependent on the electron momentum along the edge. In the case of the tilted edge the dependence of the edge state properties on the motion of the electron along the edge is more pronounced. 
These mathematical and physical conclusions are quite general and give hope to apply them to edge states in graphene.

\section{Acknowledgments}

This research was also funded by the European Social Fund under the Global Grant Measure (Grant No. VP1-3.1-ŠMM-07-K-02-046).

\section{References}

[1] A.H. Castro Neto, F. Guinea, N.M.R. Peres, K.S. Novoselov, and A.K. Geim, The eletronic properties of graphene, Rev. Mod. Phys. 81, 109 (2009).

[2] K. Wakabayashi, K. Sasaki, T. Nakanishi, and T. Enoki, Electronic states of graphene nanorib- bons and analytical solutions, Sci. Technol. Adv. Mater. 11, 054504 (2010).

[3] C.I. Kane and E.J. Male, $Z_{2}$ topologial order and the quantum spin Hall effect, Phys. Rev. Lett. 95, 146802 (2005).

[4] M. Fujita, K. Wakabayashi, K. Nakada, and K. Kusakabe, Peculiar loalized state at zigzag graphite edge, J. Phys. Soc. Jpn. 65, 1920 (1996).

[5] K. Imura, A. Yamakage, S. Mao, A. Hotta, and Y. Kuramoto, Zigzag edge modes in a $Z_{2}$ topological insulator: Reentrance and completely flat spectrum, Phys. Rev. B 82, 085118 (2010).

[6] H. Bethe, Zur Theorie der Metalle. I. Eigenwerte und Eigenfunktionen der linearen Atomkette, Z. Phys. 71, 205 (1931).

[7] D.R. Hofstadder, Energy levels and wave functions of Bloch eletrons in rational and irrational magnetic fields, Phys. Rev. B 14, 2239 (1976).

[8] G. Kiršanskas and A. Matulis, Persistent currents and Bethe Ansatz, Acta Phys. Pol. A 119, 158 (2011).

\title{
TRANSLIACINĖ KRAŠTINĖS BŪSENOS SIMETRIJA
}

\author{
A. Matulis ${ }^{\mathrm{a}, \mathrm{b}}$ \\ ${ }^{a}$ Fiziniu ir technologijos mokslu centro Puslaidininkiu fizikos institutas, Vilnius, Lietuva \\ ${ }^{\mathrm{b}}$ Vilniaus universiteto Teorines fizikos ir astronomijos institutas, Vilnius, Lietuva
}

\begin{abstract}
Santrauka
Pasinaudojus paprasčiausiu dvimatès (2D) kvadratinès gardelès modeliu ir stipraus ryšio modelio lygtimis, pailiustruota konkurencija tarp gardelès krašto ir transliacinès simetrijos. Kraštas visada sulaužo transliaciją statmena jam kryptimi ir tuo gerokai apsunkina analizinių sprendimų paiešką. Didžiausios simetrijos krašto atveju (kada jo kryptis sutampa su vienu iš primityvių transliacijos vektorių) transliacija išilgai krašto išlieka, tai igalina redukuoti $2 \mathrm{D}$ gardelès tikrinių verčių uždavini i $1 \mathrm{D}$ grandinèlès uždavinị. Istrižo krašto atveju, kai jo kryptis nesutampa nei su vienu iš tụ transliacijos vektorių, kraštas sugadina transliacijas abejomis kryptimis. Parodoma, kad transliacijos simetrija gali būti iš dalies atstatyta pasirenkant didesni primityvujji narveli ir kitus transliacijos vektorius. Tai igalina (kaip ir anksčiau) redukuoti uždavini i $1 \mathrm{D}$, nors ir padidèja
\end{abstract}

elektrono banginès funkcijos komponenčiu skaičius, o dèl sumažéjusios Brijueno zonos atsiranda papildomos energijos šakos. Parodoma, kad gauti 1D uždaviniai gali būti išspręsti Bethe Ansatz metodu skaitmeniškai patikrinant gautus rezultatus. Panaudojant pasiūlyta skaičiavimo technika išnagrinètos pagrindinès kraštinių būsenų savybès. Parodyta, kad yra dvi priežastys, lemiančios tos būsenos atsiradimą. Viena jų - skirtingas lokalinis kraštinių gardelès mazgų potencialas; antroji - dinaminè, atsirandanti dèl modifikuoto elektrono tuneliavimo efektyvumo išilgai krašto. Jeigu didžiausios simetrijos krašto atveju tik antroji lemia skirtingą tolydinès juostos minimumo kraštinès būsenos energijos priklausomybę nuo elektrono impulso išilgai krašto, tai ịstrižas kraštas gerokai sumaišo tụ dviejų priežasčių vaidmeni, lemdamas didesnę išilginio elektrono judejjimo įtaką kraštinès būsenos spektrui. 